(C) Elsevier/INRA

\title{
Influence of amino-acid concentration in the culture medium on the rate of amino-acid incorporation into protein and amino-acid oxidation of cultured chicken hepatocytes
}

\author{
JM Lopes *, M Larbier \\ INRA, Station de Recherches Avicoles, 37380 Nouzilly, France
}

(Received 21 June1993; accepted 3 February 1994)

\begin{abstract}
Summary - Hepatocytes from a 70-d-old male broiler were dissociated using a modified technique of double perfusion with an isotonic solution through the jejunum mesenteric and pancreatic veins followed by collagenase perfusion. A basal medium was made up with the same amino-acid composition of the whole chicken egg, diluted 25 times. Dilutions of $1: 1,1: 2,1: 4,1: 20,1: 40$ and 1:80 of the basal medium constituted the experimental treatments. Amino-acid incorporation into protein and amino-acid oxidation were determined by counting the radioactivity of $\left[{ }^{3} \mathrm{H}\right]$-leucine present in cellular proteins and the ${ }^{14} \mathrm{CO}_{2}$ released by the cells for 6 periods of time. The rate of amino-acid incorporation into cellular proteins was proportional to the concentration of amino acids in the culture medium, indicating their effect on the regulation of protein synthesis. At least $6 \mathrm{~h}$ incubation is needed to reach the maximal values of incorporation. Media containing large amounts of amino acids also showed higher values for oxidation, but the ratio oxidation/incorporation was higher when the amino-acid concentration in the medium was low.
\end{abstract}

amino acid / protein synthesis / oxidation / chicken hepatocytes

Résumé - Influence de la concentration en acides aminés du milieu de culture sur la vitesse d'incorporation des acides aminés dans les protéines et sur l'oxydation des acides aminés mesurés dans les hépatocytes de poulet en culture. Des hépatocytes sont préparés à partir de foie de poulets mâles âgés de $70 \mathrm{j}$. Ils sont dissociés grâce à la perfusion d'une solution isotonique suivie de collagénase, à la fois dans les veines mésentérique et pancréatique. Le milieu de base présente la même composition en acides aminés que l'cuú de poule avec une concentration divisée par 25 . Les milieux expérimentaux sont ensuite obtenus en diluant le milieu de base au 1/1, 1/2, 1/4, 1/20, 1/40 et 1/80. L'incorporation des acides aminés dans les protéines et leur oxydation sont déterminées par comptage de la radioactivité de la [3H]-Leucine incorporée et $d u{ }^{14} \mathrm{CO}_{2}$ expiré par les cellules. Les mesures sont effectuées pour 6 temps d'incubation. La vitesse d'incorporation des acides aminés dans les protéines cellulaires est proportionnelle à leur concentration dans les milieux de culture, indiquant leur effet sur la régulation de la protéosynthèse. Au moins $6 \mathrm{~h}$ d'incubation sont nécessaires pour atteindre la vitesse d'incorporation maximum. Les plus fortes valeurs d'oxydation sont obtenues pour les milieux les plus riches en acides aminés. En revanche, le rapport oxydation/incorporation est plus élevé quand la concentration en acides aminés du milieu est faible. 


\section{INTRODUCTION}

2

In the last 25 years, studies with hepatocytes of different species, including humans, have been greatly improved. After the introduction of the enzymatic method of collagenase on cell isolation, developed by Howard et al (1967) and modified by Berry and Friend (1969), the use of heptocytes has increased considerably.

Isolated liver cells of mammals (such as rat hepatocytes) are currently utilized in many fields of study, such as pathology, physiology, biochemistry, metabolism and pharmacology, because the freshly dispersed cells or primary cell cultures are more likely to retain specific organ functions (Weigand et al, 1971). This cellular model is routinely used as a model to study human metabolic disturbances or diseases.

Although hepatocyte culture in mammals is widely used, there are few studies concerning bird hepatocytes in culture. Isolating chicken hepatocytes may be an important step for the understanding of protein and lipid metabolism in this species. We are interested in developing studies on protein metabolism in chicken hepatocytes, as a model for future work on the nutritional requirements of poultry. Chickens liver cells differ from those of other species (eg, the size of cells, the capability of cellular multiplication in monolayer culture, and nutrient requirements (Capuzzi et al, 1974)).

In the few studies concerning chicken hepatocytes found in the literature, their isolation is almost always adapted from techniques used for rat cells (Seglen, 1976). This study developed a new method of cell isolation based on the work of Schreiber and Schreiber (1973), Capuzzi et al (1974), Seglen (1976), and Schultz and Mistry (1981).

For preparation of culture media, both for cell adherence or culture incubation, previous formulations were based on the pro- portion of amino acids in the chicken egg (Orr and Watt, 1957; USDA, 1976; Sauveur, 1988). There were 2 reasons for this choice. Firstly, the development of a chick embryo occurs exclusively at the expense of the egg nutrient content. Therefore, the egg contains all amino acids required and in quantities and proportions that are ideal for embryonic development. Secondly, egg protein is considered as possessing a higher biological value for monogastric animals.

The objective of this work was to study the effects of amino-acid concentrations in the culture medium on the amino-acid incorporation into cellular proteins and the aminoacid degradation in isolated monolayer cultured chicken hepatocytes.

\section{MATERIALS AND METHODS}

\section{Materials}

A 70-d-old ISA male broiler, from INRA (Institut National de la Recherche Agronomique, Station de Recherches Avicoles, 37380 Nouzilly, France) was used. We used Zoletil 100 (tiletamine, $250 \mathrm{~g}$; and zolazepam, $250 \mathrm{mg} / 5 \mathrm{ml}$ ) from Reading Laboratories as an anesthetic. Heparin (5000 $\mathrm{Ul} / \mathrm{ml}$ ) was purchased from Hoffmann La Rohe. $N$ (2-Hydroxyethyl)piperazine- $N^{\prime}$-(2-ethanesulfonic acid) (HEPES), glucose, trypan blue, and methylbenzethonium hydroxide were obtained from Sigma Chemical $\mathrm{Co}$. Amino acids, minerals, vitamins, chicken and calf fetal serums, antibiotics (penicillin + streptomycin) and sodium pyruvate were purchased from Gibco. Collagenase $(0.215$ $\mathrm{U} / \mathrm{mg}$ ) was obtained from Boehringer. Labelled amino acids were purchased from Amersham. Disposable plastic cell culture flasks (Corning) were obtained through Poly-Labo.

\section{Culture media}

Most of experiments done with hepatocytes of various species utilize commercial synthetic nutritive culture media, such as Leibovitz, Eagle, Dul- 
becco, McCoy and Williams. In a very few cases, Schwarze et al (1982) made their own medium to study the nutrient requirements of isolated cells. At present, there is no specific culture medium for chicken hepatocytes. Therefore, a medium was made up based on the amino-acid composition of a chicken egg, which was diluted several times in order to obtain a medium similar to those utilized in cultured hepatic cells of other species like rat, trout, rabbit, and human. Using the data of Orr and Watt (1957), USDA (1976), and Sauveur (1988), the average amino-acid composition of the total egg was calculated. A mixture was made of synthetic amino acids in the same proportions observed in the whole chicken egg diluted 25 times. This is called 'basal medium' (table I). To make the other experimental media, the amino-acid concentration varied but all other components remained unchanged.

The basal medium composition was $2-5$ times more concentrated in protein, compared with Lejbovitz $L-15$ and Williams $E$ media, which are used mostly for culture of rat hepatocytes. Therefore dilutions of $1: 1,1: 2,1: 4,1: 20,1: 40$ and $1: 80$ of the basal medium were made, to constitute the experimental treatments. One medium without amino acids was included as a control to study the effect of the intracellular amino acids on protein synthesis and amino-acid oxidation.

The adhesion medium used in the first $24 \mathrm{~h}$ of culture had the same composition as the basal medium with addition of chicken serum (35 $\mathrm{ml}$ ), fetal calf serum $(25 \mathrm{ml})$ and $10 \mathrm{ml}$ penicillin-streptomycin solution ( $10000 \mathrm{U}$ and $10000 \mu \mathrm{g} / \mathrm{ml}$ respectively) per liter.

\section{Isolation of hepatocytes}

The hepatocytes were isolated according to the technique described by Seglen (1976) and modified by JP Caffin in 1990 (personal communication, Université Pierre-et-Marie-Curie, Paris VI, France). A 70-d-old male broiler, that weighed $\approx 3.5 \mathrm{~kg}$ and had been fed ad libitum was anesthetized through an intramuscular injection of $1.5 \mathrm{ml}$ Zoletil 100 in the breast. After $15 \mathrm{~min}$, a mixture of $1.5 \mathrm{ml}$ heparin and $0.3 \mathrm{ml}$ Zoletil 100 was injected in the tibial vein. Abdominal feathers were cleaned with a liquid soap and the bird was placed ventral up. A transversal abdominal incision was made just below the carina and exten- ded on both sides in the direction of the ribs. The gut was exposed, in order to place Vénocath 16 catheters (Abbot Ltd, Sligo, Ireland) in the jejunum mesenteric and pancreatic veins, which were

Table I. Composition of the basal culture medium.

\section{Components Concentration ( $\mathrm{mg} / \mathrm{l})$}

\begin{tabular}{|c|c|}
\hline $\begin{array}{l}\mathrm{CaCl}_{2} \\
\mathrm{KCl}\end{array}$ & $\begin{array}{l}200 \\
400\end{array}$ \\
\hline $\mathrm{MgSO}_{4}$ & 97.7 \\
\hline $\mathrm{NaCl}$ & 6800 \\
\hline $\mathrm{NaHCO}_{3}$ & 350 \\
\hline Sodium pyruvate & 33 \\
\hline $\mathrm{NaH}_{2} \mathrm{PO}_{4} \cdot \mathrm{H}_{2} \mathrm{O}$ & 140 \\
\hline Calcium pantothenate & 1.00 \\
\hline Choline chloride & 1.00 \\
\hline Folic acid & 1.00 \\
\hline$i-\mid$ nositol & 2.00 \\
\hline Nicotinamide & 1.00 \\
\hline Pyridoxal $\mathrm{HCl}$ & 1.00 \\
\hline Riboflavine & 0.10 \\
\hline Thiamine $\mathrm{HCl}$ & 1.00 \\
\hline L-Aspartic acid & 420 \\
\hline L-Glutamic acid & 587.6 \\
\hline L-Alanine & 274.4 \\
\hline L-Arginine & 254.8 \\
\hline L-Cysteine & 112.8 \\
\hline Glycine & 160.8 \\
\hline L-Histidine & 114.4 \\
\hline L-Isoleucine & 291.2 \\
\hline L-Leucine & 414.4 \\
\hline L-Lysine & 311.6 \\
\hline L-Methionine & 152.4 \\
\hline L-Phenylalanine & 255.6 \\
\hline L-Proline & 196.8 \\
\hline L-Serine & 372.8 \\
\hline L-Threonine & 233.2 \\
\hline L-Tryptophan & 77.2 \\
\hline L-Tyrosine & 198.0 \\
\hline L-Valine & 250.8 \\
\hline D-Glucose & 2000 \\
\hline Phenol red & 10 \\
\hline HEPES buffer $1 \mathrm{M}, \mathrm{ml}$ a & 25 \\
\hline Deionized and distilled $\mathrm{H}_{2} \mathrm{O}$ to & $1000 \mathrm{ml}$ \\
\hline
\end{tabular}

a Composition per liter: HEPES, $260.3 \mathrm{~g} ; \mathrm{NaCl}, 800 \mathrm{~g}$; $\mathrm{KCl}, 20 \mathrm{~g} ; \mathrm{Na}_{2} \mathrm{HPO}_{4}, 10 \mathrm{~g}$; deionized and distilled $\mathrm{H}_{2} \mathrm{O}$ to $1000 \mathrm{ml}$. 
tied up through a surgery silk ligature, to avoid reflux of perfusing solution.

\section{Perfusion}

The circuit was rinsed twice with sterile water and perfusing solution, respectively. When the catheter was inserted the pump output was minimal in order to avoid air bubbles. Immediately after that, the apex of the heart was cut with a surgical scissors, to make a rapid bleeding and allow the perfusion of isotonic solution $(\mathrm{NaCl} 0.137 \mathrm{M} ; \mathrm{KCl}$ $0.0027 \mathrm{M} ; \mathrm{Na}_{2} \mathrm{HPO}_{4} 0.0007 \mathrm{M}$; and HEPES free acid $0.010 \mathrm{M}$ ) at $\mathrm{pH} 7.4$ to pass through. At the same time, the pump output was increased to 30 $\mathrm{ml} / \mathrm{min}$ of perfusion.

\section{Hepatocyte dissociation}

After 15 min perfusion, the liver became uniformly pale, indicating that the perfusion was accomplished and the liver was ready for the cell dissociation. A solution of sterilized collagenase $(0.2 \mathrm{mg} / \mathrm{ml})$ was then perfused at a final volume of $350 \mathrm{ml}$. At this time, the temperature of the liver was maintained around $33^{\circ} \mathrm{C}$ by an infrared lamp. The output of perfusion was then reduced to $20 \mathrm{ml} / \mathrm{min}$. After cell dissociation, the liver was carefully removed from the abdominal cavity, the gall bladder was eliminated, and the liver was washed with $100 \mathrm{ml}$ sterilized water and placed in a sterila Petri dish.

\section{Hepatocyte preparation}

In a laminar fume hood, $50 \mathrm{ml}$ cold perfusing solution was added to the Petri dish, and the liver was gently lacerated with 2 sterile Teflon spatula to promote good cellular suspension. This suspension was first filtered through 2 crossed layers of cheesecloth. A second filtration was carried out through $60 \mu \mathrm{m}$ nylon mesh. The cellular suspension was centrifuged for $2 \mathrm{~min}$ at $70 \mathrm{G}$. The supematant was eliminated, replaced immediately by cold isotonic solution, and the cell pellets were well mixed. This operation was repeated 3 times in order to get a cellular pad free of red globules and eliminate the majority of the dead cells.
Finally, $10 \mathrm{ml}$ cold perfusing solution was added to the cells and filtered through a $37 \mu \mathrm{m}$ nylon mesh. Cell viability was evaluated by the method of trypan blue exclusion. The yield obtained in these conditions was about $90 \%$.

\section{Cell culture, determination of protein synthesis and amino-acid oxidation}

A density of $7 \times 10^{6}$ cells were seeded in the bottom of each plastic culture flask ( $10 \mathrm{~cm}^{2}$ surface), containing $2 \mathrm{ml}$ adhesion medium, and incubated at $37^{\circ} \mathrm{C}$ and $5 \% \mathrm{CO}_{2}$ for $24 \mathrm{~h}$. The day after, the adhesion medium was eliminated through careful vacuum aspiration and the flasks were rinsed with $2 \mathrm{ml}$ HEPES buffer. Thereafter, $3 \mathrm{ml}$ experimental culture media was added to each flask. The addition of $0.17 \mu \mathrm{Ci} L-[4,5-3 \mathrm{H}]$-leucine (5.7 TBq $/ \mathrm{mmol}$ or $154 \mathrm{Ci} / \mathrm{mmol}) / \mathrm{ml}$ and $0.033 \mu \mathrm{Ci}$ $\left[\mathrm{U}-{ }^{14} \mathrm{C}\right)$ protein hydrolysate $(1.85 \mathrm{GBq} /$ milliatom or $50 \mathrm{mCi} / \mathrm{milliatom}$ carbon $) / \mathrm{ml}$ per flask was the same for all treatments. The flasks were plugged with a rubber cap, with a suspended plastic center well, and filled with $200 \mu$ methylbenzetonium to trap the $\mathrm{CO}_{2}$ released by the cells. They were reincubated in the same conditions as above. To study the kinetics of amino-acid incorporation and oxidation, 6 flasks of each treatment were taken out at various periods of time $(3,6,12$, 18,24 and $30 \mathrm{~h}$ ), after the beginning of reincubation and immediately placed in a freezer at $-20^{\circ} \mathrm{C}$ until required for analysis.

To measure the ${ }^{14} \mathrm{CO}_{2}$, which is a product of amino-acid oxidation, the flasks were opened, and the wells were removed and placed directly in vials containing $3 \mathrm{ml}$ scintillation fluid (OptiPhase 'HiSafe' II - LKB Scintillation Products, Loughborough, England) for counting of radioactivity, in a TRI-CARB 460 CD Liquid Scintillation System (Packard Instruments, Inc, Zurich, Switzerland).

Cells were detached by $2 \mathrm{ml} 0.1 \mathrm{M}$ $\mathrm{NaOH} / 0.4 \%$ (wt/vol) deoxycholate, put into conic centrifugation tubes, and protein was precipitated by $1 \mathrm{ml} 80 \%$ sulfosalysilic acid. The cells were centrifuged at $3900 \mathrm{G}$ for $15 \mathrm{~min}$. The supernatant was discarded and the precipitate was dissolved in $0.5 \mathrm{ml} 70 \%$ perchloric acid. The solution was mechanically agitated and then transferred to a vial containing $3 \mathrm{ml}$ scintillation fluid for counting the incorporation of $\left[{ }^{3} \mathrm{H}\right]$-leucine into cellular protein. 


\section{Statistical analysis}

Protein synthesis was estimated by measuring the incorporation of leucine ( $\mathrm{nmol}$ ) into protein. The DPM in the precipitate was divided by the specific activity of [ $\left.{ }^{3} \mathrm{H}\right]$-leucine in each flask. For oxidation, the amount of leucine (nmol) was obtained by dividing the DPM of $\mathrm{CO}_{2}$ trapped in the well by the specific activity of $\left[{ }^{14} \mathrm{C}\right]$-leucine in each flask.

Data ( 7 amino-acid concentration for 6 intervals of time for 6 replicates) were submitted to ANOVA and a comparison of means was done by Tukey's test. The calculations were performed using a SYSTAT software program (Wilkinson, Leyland, Systat Inc, Evanston IL, USA).

\section{RESULTS AND DISCUSSION}

\section{Incorporation of amino acid into protein}

The incorporation of radioactive amino acids in cellular proteins increases with the aug. mentation of the amino-acid concentration in the culture medium (table II). Higher concentrations of amino acids lead to an increase in the incorporation of radioactive $\left[{ }^{3} \mathrm{H}\right]$-leu- cine in the cellular protein, and media with very low amino-acid concentrations failed to stimulate protein synthesis, indicating that amino acids may regulate the rate of their incorporation into protein (fig 1).

A pronounced stimulation on protein synthesis in rat hepatocytes was also observed by Seglen et al (1980), when they added a balanced amino-acid mixture at concentrations up to 12.5 times the normal plasma levels.

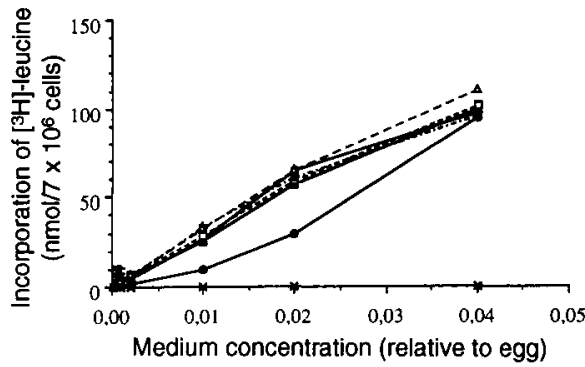

Fig 1. Rates of $\left[{ }^{3} \mathrm{H}\right]$-leucine incorporation in isolated chicken hepatocytes according to the variations in amino-acid concentration in the culture medium, as described in Materials and methods. Each point represents mean \pm SEM of 6 replicates. Incubation time $-x-: 0 h$;

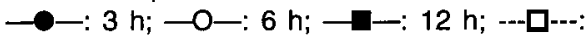
$18 \mathrm{~h} ;-.-. \Delta .-.-: 24 \mathrm{~h} ;-\Delta-: 30 \mathrm{~h}$.

Table II. Incorporation of [3H]-leucine into protein and ${ }^{14} \mathrm{C}$-leucine oxidation of chicken hepatocytes under different amino-acid concentrations in the culture medium.

\begin{tabular}{lcc} 
Medium dilution a & Protein synthesis b.c & Amino-acid oxidation \\
\hline & & \\
$1: 25$ & $100.140 \pm 5.72^{\mathrm{f}}$ & $2.795 \pm 0.699^{\mathrm{f}}$ \\
$1: 50$ & $50.632 \pm 13.32 \mathrm{~g}$ & $1.857 \pm 0.559 \mathrm{~g}$ \\
$1: 100$ & $26.000 \pm 8.77 \mathrm{~g}$ & $1.276 \pm 0.492^{\mathrm{h}}$ \\
$1: 500$ & $5.540 \pm 1.81^{\mathrm{h}}$ & $0.446 \pm 0.198^{\mathrm{i}}$ \\
$1: 1000$ & $2.720 \pm 0.72^{\mathrm{h}}$ & $0.251 \pm 0.117^{\mathrm{i}}$ \\
$1: 2000$ & $1.940 \pm 0.46^{\mathrm{h}}$ & $0.202 \pm 0.085^{\mathrm{h}}$ \\
0 (control) $\mathrm{e}$ & $0.140 \pm 0.04^{\mathrm{h}}$ & $0.016 \pm 0.006$
\end{tabular}

\footnotetext{
a Dilution of amino acids in relation to the whole egg content; b expressed as nmol [3H]-leucine incorporated in cell protein; c means \pm SEM of 6 replicates of 6 periods of incubation times; d expressed as nmol $\left[{ }^{14} \mathrm{CO}_{2}\right]$ released; ${ }^{e}$ no amino acids added. Means within rows with no common superscripts differ significantly $(P<0.05)$ by Tukey's test.
} 
The current results show that the rate of amino-acid incorporation in cellular protein was proportional to the amino-acid concentration in the medium. For the less concentrated samples $(1: 80$ and $1: 40)$, the differences were not significant, due to the very low incorporation in both media. These results agree with observations of Everson et al (1989), who showed that one or all essential amino acids can affect the synthesis of protein, and this situation can be reversed by the readdition of the deficient amino acid(s). On the other hand, for more concentrated media, 1:1 compared to $1: 2$, the rate of incorporation is only 1.5 times higher for the first, probably because the concentration in amino acids of medium 1:1 is close to the optimal level for the cells.

The incorporation of labelled amino acid in protein is also time dependent, and it varies according to the amino-acid concentration. In figure 2, it is shown that for the most concentrated medium, the peak of incorporation was reached within $3 \mathrm{~h}$ of cell incubation and for all other treatments at least $6 \mathrm{~h}$ were needed to do this. However in rats, Flaim et al (1982) observed that 20 min was enough to depress the synthesis of protein when an amino-acid-deficient medium is perfused, when compared with a

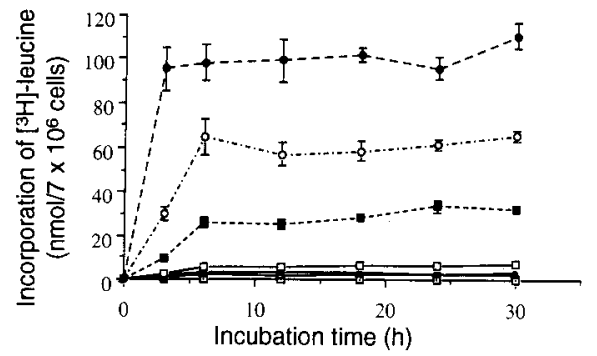

Fig 2. Incorporation of [ $\left.{ }^{3} \mathrm{H}\right]$-Leucine into cellular proteins of cultured chicken hepatocytes with time, as described in Materials and methods. Each point represents mean \pm SEM of 6 replicates. Medium concentration (relative to egg): 一回—: 0.0001; - - -: 0.0005; - $\mathbf{\Delta - :}$ $0.0010 ;-\square-: 0.0020 ; . .-\square \ldots ; 0.0100$; -.O-.-: $0.0200 ; \longrightarrow \longrightarrow 0.0400$. medium with optimal concentration. Therefore, chicken hepatocytes seem to synthesize different amounts of proteins, depending not only on the amino-acid concentration in the culture medium, but also on the time of incubation.

\section{Oxidation of amino acids}

The ${ }^{14} \mathrm{CO}_{2}$ derived from proteolysis and subsequent oxidation of amino acids, as well as from the process of synthesis, followed a proportional profile related to the concentration of amino acids in the incubation media (fig 3).

At all the times studied, both the aminoacid oxidation and the amino-acid incorporation into protein increased with the augmentation of amino-acid concentration in the culture medium (fig 4) but the ratio oxidation/incorporation (table II and fig 5) increases as the amino-acid concentration in the media diminished, probably because the isolated amino acids originating from proteolysis could not be used in the 'turnover' process, due to the lack of other

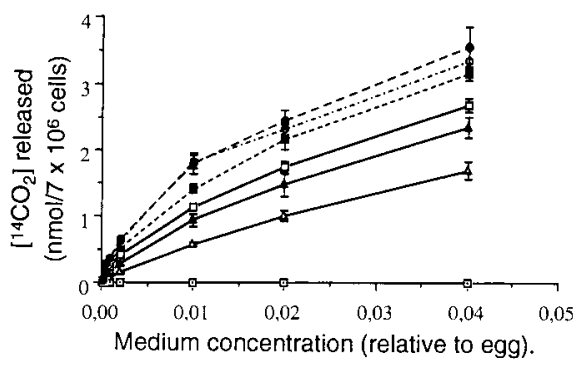

Fig 3. Rates of amino-acid oxidation, measured as the $\left[{ }^{14} \mathrm{CO}_{2}\right]$ released by chicken hepatocytes according to the amino-acid concentration in the culture medium, in different periods of incubation time, as described in Materials and methods. Each point represents mean \pm SEM of 6 replicates. Incubation time - $\mathbf{0 - :} 0 \mathrm{~h} ;-\Delta-: 3 \mathrm{~h} ;-\mathbf{A -}$

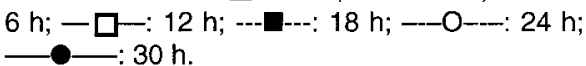




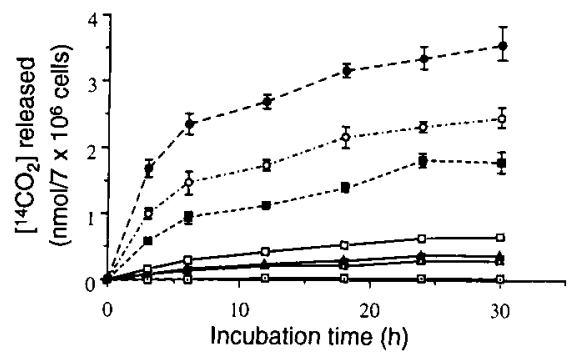

Fig 4. Release of $\left[{ }^{14} \mathrm{CO}_{2}\right]$ by cultured chicken hepatocytes with time, incubated in culture media with different concentrations of amino acids, as described in Materials and methods. Each point represents mean \pm SEM of 6 replicates. Medium concentration (relative to egg): 一田-: $0.0001 ;-\Delta-: 0.0005 ;-\mathbf{A}-$ : 0.0010 ; - $\square-$ : $0.0020 ;. .-1 . .: 0.0100$; -.-O-.-: $0.0200 ; \longrightarrow \longrightarrow$ - 0.0400 .

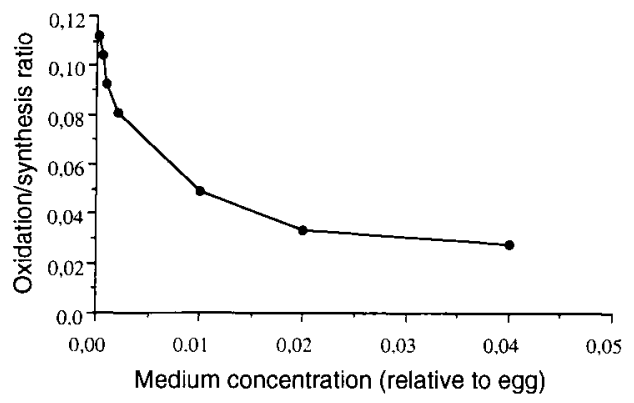

Fig 5. Negative relationship between oxidation/incorporation ratio and amino-acid concentration in the culture medium in cultured chicken hepatocytes. Each point represents mean of 6 replicates of 6 periods of time.

essential amino acids, and consequently they were used as sources of energy for the cell metabolism. This effect has been already shown by Seglen and Solheim (1978), when they described the importance of amino acids to the liver cells, because they serve both as protein precursors and energy substrates.
In an extensive work, Seglen (1976) demonstrated that isolated rat liver cells can synthesize protien and RNA, and if they are incubated in a substrate-free medium, they give off amino acids and urea, indicating the occurrence of protein degradation.

The rate of protein breakdown of hepatocytes in primary monolayer cultures was regulated by the amino-acid composition of the culture medium, according to Sommercorn and Swick (1981), where the inhibition of amino-acid degradation was due to the low levels of essential amino acids in the medis $n$, mainly methionine, phenylalanine, and tryptophan. Similar results were obtained by Schwarze et al (1982), where high concentrations of amino acids reduced the overall rate of protein degradation from 5 to $1.5 \% / \mathrm{h}$, demonstrating that amino acids have an anticatabolic effect. These findings are in good agreement with the current results, which show clearly that the ratio oxidation/incorporation diminishes when low levels of amino acids in the culture are used.

In the conditions of this experiment, it can be concluded that: 1) the incorporation of amino-acid label into the protein of chicken hepatocytes is directly proportional to the concentration of amino acids in the culture medium; 2) $6 \mathrm{~h}$ incubation is needed to get a maximal incorporation of amino acid in the protein of isolated chicken hepatocytes; and 3) the oxidation of amino acids is also directly proportional to the medium concentration, but the ratio oxidation/aminoacid incorporation is higher for media with low concentration of amino acids.

\section{ACKNOWLEDGMENTS}

The authors wish to thank JP Caffin, M Taouis, and $S$ Tesseraud for excellent technical assistance and $R$ Peresson for her help in the experimental work. This work was supported by INRA and Consello Nacional de Desenvolvimento Científico e Tecnológico (CNPq, Brazil). 


\section{REFERENCES}

Berry MN, Friend DS (1969) High yield preparation of isolated rat liver parenchimal cells. $J \mathrm{Cell} \mathrm{Biol} \mathrm{43,} \mathrm{506-520}$

Capuzzi DM, Rothman V, Margolis S (1974) The regulation of lipogenesis by cyclic nucleotides in intact hepatocytes prepared by a simplified technique. J Biol Chem 249, 1286-1294, 9

Everson WV, Flaim KE, Susco DM, Kimball SR, Jefferson LS (1989) Effect of amino-acid deprivation on initiation of protein synthesis in rat hepatocytes. Am J Physiol 256 (Cell Physiol 25) $\mathrm{C} 18-\mathrm{C} 27$

Flaim KE, Peavy DE, Everson WV, Jefferson LS (1982) The role of amino acids in the regulation of protein synthesis in perfused rat liver. $J$ Biol Chem 257, 2932-2938

Howard RB, Christensen AK, Gibbs FA, Pesch LA (1967) The enzymatic preparation of isolated parenchimal cells from rat liver. $J$ Cell Biol 35, 675-684

Orr ML, Watt BK (1957) Amino-acid content in foods. In: US Department of Agriculture Home Economics Research Report 4. US Government Printing Office, Washington, DC, 48-49

Sauveur B (1988) Reproduction de Volailles et production d'ceufs. INRA, Paris, France

Schreiber G, Schreiber M (1973) The preparation of single-cell suspensions from liver and their use for the study of protein synthesis. Subcell Biochem 2, 307-353
Schultz P, Mistry SP (1981) A technique for the isolation of chicken hepatocytes and their use in a study of gluconeogenesis. Poultry Sci 60, 643-652

Schwarze PE, Solheim AE, Seglen PO (1982) Amino-acid and energy requirements for rat hepatocytes in primary culture. In vitro 18, 43 54

Seglen PO (1976) Preparation of isolated rat liver cells. In: Methods in Cell Biology (DM Prescott, ed) Academic Press, New York, NY, vol 13

Seglen PO, Solheim AE (1978) Effects of aminooxyacetate, alanine and other amino acids on protein synthesis in isolated rat hepatocytes. Biochim Biophys Acta 520, 630-641

Seglen PO, Solheim AE, Grinde B, Gordon PB, Schwarze PE, Gjessing R, Poli A (1980) Amino-acid control of protein synthesis and degradation in isolated rat hepatocytes. Ann NY Acad Sci 349, 1-17

Sommercom JM, Swick RW (1981) Protein degradation in primary monolayer cultures of adult rat hepatocytes. J Biol Chem 256, 4916-4821

USDA (1976) Composition of Foods. Dairy and Egg Products-Raw, Processed, Prepared. Agriculture Handbook No 8-1 USDA, Washington, $\mathrm{DC}$

Weigand K, Müller M, Urban J, Schreiber G (1971) Intact endoplasmic reticulum and albumin synthesis in rat liver cell suspensions. Exp Cell Res 67, 27-32 